\title{
Desapropriações e remoções na implantação de projetos de infraestrutura: entre avanços e oportunidades
}

\section{Anna Carolina Migueis Pereira}

Mestre em Direito Público e Bacharel em Direito pela Universidade do Estado do Rio de Janeiro (UERJ). Especialista em Direito do Estado e da Regulação pela Fundação Getúlio Vargas (FGV Direito Rio). Professora Convidada da Pós-Graduação e Cursos de Extensão da FGV Direito Rio. Procuradora do Estado do Rio de Janeiro. E-mail: annacmigueis@gmail.com

\section{Resumo}

As desapropriações e realocações são fundamentais para a implantação de projetos de infraestrutura, sendo seu sucesso fundamental para a viabilidade do empreendimento. $O$ presente artigo tem como objetivo analisar as principais inovações já existentes e algumas proposições, no que se refere às desapropriações e às remoções, com o intuito de trazer maior eficiência para esses processos.

Palavras-chave

Desapropriação; Realocação; Infraestrutura; Consensualidade; Eficiência.

\section{Dissappropriations and removals in the implementation of infrastructure projects: Between lost advances and opportunities}

\begin{abstract}
Expropriation and reallocation processes are a very important component in the success or failure of infrastructure projects. The present article aims to analyze inovations already in progress and, also, offer a few propositions in order to bring more efficiency to these processes.
\end{abstract}

Keywords

Expropriation; Reallocation; Infrastructure; Consensuality; Efficiency.

\section{Sumário}

Introdução. 1. Desapropriações e projetos de infraestrutura: algumas propostas. 1.1. Ampliação do rol de legitimados para a propositura da ação de desapropriação e 
repartição dos riscos da demanda. 1.2. A desapropriação por zona como instrumento de remuneração de parceiros privados e concessionários. 2. Desapropriações e remoções: para além da judicialização. 2.1. Maior proteção aos desenvolvidos nos processos de remoções e desocupações. 2.2. Normatização e incentivos para a desapropriação amigável. 3. Considerações finais.

\section{Introdução}

A implantação de projetos de infraestrutura não raro envolve centenas - às vezes milhares - de desapropriações e remoções. O desenvolvimento de projetos de grande porte, como a construção e ampliação de rodovias, ferrovias, vias expressas em áreas urbanas, usinas hidrelétricas, assim como qualquer projeto de igual magnitude, necessariamente demandará o desalojamento de considerável número de pessoas; mas, se, de um lado, é fato que expropriações e desocupações trazem inúmeros transtornos às pessoas atingidas pelo processo ${ }^{1}$, por outro, também é certo que tais procedimentos são imprescindíveis para a concretização dos projetos.

Diante da inevitabilidade das desapropriações e remoções e da necessidade de sua conclusão para que as obras de infraestrutura possam avançar, sobretudo nos projetos greenfield, que envolvem a implantação de empreendimento novo ("do zero"), mostra-se especialmente salutar a busca de mecanismos para torná-las mais céleres e, ao mesmo tempo, mais justas para os envolvidos, garantindo-lhes compensações compatíveis com os transtornos inerentes a uma mudança forçada e, ainda, que permitam a sua realocação em locais dignos.

No ordenamento brasileiro, as desapropriações são reguladas, sobretudo, pelo Decreto-lei no 3.365/1941 (DL 3.365/41), que trata da desapropriação por utilidade pública. Este marco legal, editado durante o período do Estado Novo, carrega traços eminentemente autoritários e uma baixa preocupação com o expropriado, restrita, ainda que de forma incompleta, a uma dimensão patrimonial. Isso pode ser visto, por exemplo, na limitação contida no seu art. 33, que prevê que o desapropriado somente poderá sacar $80 \%$ (oitenta por cento) do valor depositado em juízo pelo expropriante quando este requerer a imissão provisória na posse - muito embora neste momento o expropriado

\footnotetext{
${ }^{1}$ Sobre os transtornos que a desapropriação pode trazer para as pessoas afetadas, vide: ROLNIK, Raquel. Você já foi desapropriado? Foi feliz? Disponível em: <https://raquelrolnik.wordpress.com/2013/07/25/voce-ja-foi-desapropriado-foi-feliz/> Acesso em 14.12.2016.
}

Revista Publicum

Rio de Janeiro, v. 3, n. 2, 2017, p. 134-165

http://www.e-publicacoes.uerj.br/index.php/publicum

DOI: $10.12957 /$ publicum.2017.29000 
seja destituído da posse do bem em caráter praticamente definitivo, visto que somente retomará o bem no caso de desistência da ação pelo expropriante.

Além disso, o foco do DL 3.365/41 reside claramente nos proprietários que possuem registro formal, não apresentando (ao menos não em sua redação originária) nenhum dispositivo que regule as hipóteses de remoções de possuidores e pessoas que não tenhamjusto título de propriedade - frequentemente indivíduos de baixa renda e em situação de vulnerabilidade. Pelo contrário: seu art. 20 estabelece que a contestação em ações de desapropriação somente pode versar sobre vícios processuais ou impugnação ao preço ofertado; qualquer outra questão - como, por exemplo, a titularidade do bem e a presença de possuidores e ocupantes - deve ser discutida em ação autônoma².

Com isso, as disposições originais do Decreto-lei acabam por relegar as comunidades carentes a uma proteção insuficiente e representam claro risco social, tornando a sua revisão uma exigência para o atendimento dos interesses da coletividade, desde que em consonância com os preceitos trazidos pela Constituição de 1988.

E não só a legislação, como também a própria jurisprudência, parecem endossar a visão de maior preocupação com o proprietário formal: decisões judiciais recentes ${ }^{3}$ consolidam o entendimento de que a indenização na ação de desapropriação deve

\footnotetext{
${ }^{2}$ Admite-se também ao particular, pleitear, na contestação da ação de desapropriação, o direito de extensão, conforme regulado no art. 40 da LC 76/93. Isso porque, embora seja possível a desapropriação parcial de bens, não é possível que o Estado desaproprie uma parte relevante de um imóvel, mas deixe uma parte remanescente não passível de aproveitamento econômico. Se isso acontecer, surge, para o desapropriado, o direito de exigir do Estado que a desapropriação se estenda ao terreno inteiro e que o Estado the pague a indenização correspondente. Apesar do relativo dissenso doutrinário quanto à base legal do direito de extensão (José dos Santos Carvalho Filho sustenta que o fundamento do direito de extensão residiria no Decreto no 4.956/1903, norma anterior ao Decreto-Lei no 3365/1941, que não teria sido revogado neste ponto. Vide: CARVALHO FILHO, José dos Santos. Manual de Direito Administrativo. 23a ed. Rio de Janeiro: Lumen Juris, 2009. P. 958), entende o STJ que tal direito seria fundamentado em uma desapropriação indireta da área remanescente que não se mostra passível de aproveitamento econômico. Vejamos:

STJ, AREsp 374152, Rel. Min. Benedito Gonçalves, DJ 08 jun. 2015: "II - Do reconhecimento do direito de extensão da desapropriação à área total do imóvel: No que respeita ao reconhecimento do alegado direito de extensão da desapropriação à área total do imóvel, tem-se que o acórdão recorrido ao analisar a questão baseou-se nas provas carreadas aos autos, mormente com base em laudos periciais, conforme se depreende com clareza do Voto do e. Relator. O direito de extensão ocorre quando o Poder Público invade parte de imóvel (desapropriação indireta), deixando a área remanescente de exercer qualquer atrativo em termos imobiliários, hipótese em que o expropriante deverá indenizar a totalidade do bem".

STJ, Rel. Min. Luiz Fux, primeira turma, DJ 14 jun. 2004: "ADMINISTRATIVO. DESAPROPRIAÇÃO. DIREITO DE EXTENSÃO. DECRETO № 4.956/1903. MATÉRIA FÁTICO-PROBATÓRIA. SÚMULA 07/STJ. 1. O direito de extensão ocorre quando o Poder Público invade parte de imóvel (desapropriação indireta), deixando a área remanescente de exercer qualquer atrativo em termos imobiliários, hipótese em que o expropriante deverá indenizar a totalidade do bem".

${ }^{3}$ Apelação 0043869602001401320/MG - TRF - 1ạ. Região. Comentários em:

<http://www.direitodoestado.com.br/noticias/procuradorias-comprovam-que-indenizacao-pordesapropriacao-de-terras-deve-obedecer-extensao-da-area-registrada-em-cartorio>. Acesso em: 08.08.2017
}

Revista Publicum

Rio de Janeiro, v. 3, n. 2, 2017, p. 134-165

http://www.e-publicacoes.uerj.br/index.php/publicum

DOI: 10.12957/publicum.2017.29000 
abranger apenas a área registrada do imóvel. Então, ainda à luz das limitações impostas pelo art. 20 do DL 3.365/41, eventuais discussões quanto à verificação de que, na prática, a metragem do imóvel é superior àquela constante do registro devem ser manejadas apenas em ação própria.

Em contrapartida à rígida disciplina dada às desapropriações pelo Direito Brasileiro, podemos trazer à baila a noção de Princípios do Equador, formados por um conjunto de critérios adotados por instituições financeiras para a concessão de crédito para empreendimentos que envolvam questões socioambientais, firmados originalmente em 2003, e que representam diretrizes de governança regulatória das contratações públicas ligadas a esses projetos. Trata-se, portanto, de um exemplo de autorregulação coletiva, em que agentes privados (instituições financeiras) editam normas que pretendem regular a redução dos impactos socioambientais de projetos que elas próprias irão financiar ${ }^{4}$.

Os Princípios, em vez de normatizar apenas o direito do proprietário formal a uma compensação financeira pela perda da propriedade, trabalha com a noção de "comunidade" e "pessoas afetadas pelo projeto", abrangendo também possuidores e mesmo ocupantes de imóveis que venham a ser incorporados à obra. A terceira e última versão dos Princípios foi aprovada em 2013, classificando os projetos a serem financiados a partir da magnitude dos seus impactos negativos e impulsionando a convergência em torno dos padrões socioambientais de análise, inclusive por agências de crédito à exportação, através das "abordagens comuns da $O C D E$ " , que vêm seguindo diretrizes similares, e por bancos multilaterais de desenvolvimento. Atualmente, o número de instituições financeiras signatárias, de $\mathrm{dez}^{7}$ aumentou para setenta e cinco, incluindo, na América Latina, o Chile, o que demonstra a necessidade, cada vez mais difundida, de que os projetos a serem financiados incorporem práticas seguras de gestão ambiental e tenham responsabilidade social no trato com as comunidades locais.

Além da baixa proteção àqueles que não sejam proprietários formais, outro ponto sensível do Decreto-lei no 3.365/1941 é a ausência de disciplina de um procedimento para

4 Acerca da autorregulação coletiva, vide: SENN, Myriam. Non-state regulatory regimes: understanding institutional transformations, 2011, p. 120.

${ }^{5}$ Comunidades são as comunidades locais, presentes na área de influência do projeto e diretamente afetadas por ele. Já o projeto é um empreendimento de qualquer setor, em um local determinado. O conceito engloba a ampliação ou modernização de uma unidade já existente que resulte numa mudança substancial na sua produção ou na sua função, conforme <http://www.equatorprinciples.com/resources/equator_principles_III.pdf>. Acesso em 05.11.2016.

6 ORGANISATION FOR ECONOMIC CO-OPERATION AND DEVELOPMENT. The 2012 Common Approaches. Disponível em: <http://www.oecd.org/tad/xcred/the2012commonapproaches.htm $\geq$. Acesso em: 05.11.2016.

7 ABN Amro, Barclays, Citigroup, Crédit Lyonnais, Crédit Suisse, HypoVereinsbank (HVB), Rabobank, Royal Bank of Scotland, WestLB e Westpac.

Revista Publicum

Rio de Janeiro, v. 3, n. 2, 2017, p. 134-165

http://www.e-publicacoes.uerj.br/index.php/publicum

DOI: 10.12957/publicum.2017.29000 
desapropriações e desocupações amigáveis, não trazendo nenhum incentivo para que o expropriante busque acordos extrajudiciais com os indivíduos afetados pelo projeto. A falta de mecanismos de autocomposição em matéria de expropriações e remoções acaba por retardar e encarecer ainda mais esses processos, na medida em que a ação de desapropriação traz a reboque todos os riscos inerentes às demandas judiciais em geral: demora no processamento, pouco controle das partes quanto aos rumos do processo, risco de indeferimento ou demora na imissão provisória na posse, custas processuais e honorários periciais elevados. Na mesma esteira, essa carência de apoio às aquisições e realocações amigáveis torna a implantação do projeto final - qual seja a obra de infraestrutura - mais morosa e custosa, o que, ao fim e ao cabo, acarretará cobrança de tarifas mais elevadas dos usuários e/ou maiores aportes do Poder Público para a concretização do empreendimento.

Visando atenuar essas distorções, a Medida Provisória no 700/2015 trouxe uma série de medidas que pretendiam modernizar o regime jurídico a que se submetem as expropriações, como a ampliação do rol dos legitimados para propositura de ação de desapropriação, introdução de mecanismos de compensação de ocupantes irregulares em situação de risco social que viessem a ser desalojados no curso do processo expropriatório, e a possibilidade de transferência da posse ou do domínio do bem expropriado ainda no curso da ação. A MP, entretanto, perdeu a vigência, em decorrência do término do prazo para sua votação no Congresso Nacional sem que tivesse sido apreciada.

Nesse sentido, a intenção do presente artigo é a de reavivar as discussões acerca das propostas editadas pelo Poder Executivo em 2015, bem como a de apresentar novas propostas, que, em nossa opinião, têm o potencial de aprimorar as desapropriações promovidas no Brasil, a partir de três vetores principais: (i) a adoção de mecanismos que incrementem a eficiência das desapropriações enquanto instrumento necessário para a implantação de infraestruturas, ponto em que abordaremos a questão da legitimidade ativa para a propositura de eventual ação de desapropriação e a repartição dos riscos relativos à ação com esses legitimados; e, ainda, a possibilidade de aplicação da desapropriação por zona como mecanismo de garantir a contraprestação do Poder Público ao parceiro privado em contratos de concessão e Parcerias Público-Privadas ou o incremento das receitas alternativas nas concessões comuns; (ii) a maior proteção de pessoas atingidas pelo projeto que não contem com título formal de propriedade; e (iii) a criação de incentivos para as desapropriações consensuais, de modo a gerar maior eficiência e justiça nos processos expropriatórios. 


\section{Desapropriações e projetos de infraestrutura: algumas propostas}

\subsection{Ampliação do rol de legitimados para a propositura da ação de desapropriação e repatriação dos riscos da demanda}

A ampliação do rol de legitimados ativos para a propositura de ação de desapropriação, de modo a incluir também os contratados para a realização de obras e serviços de engenharia sob os regimes de empreitada por preço global, empreitada integral e contratação integrada, já havia sido intentada pela MP 700/2015. Com essa ampliação, poderiam propor ação de desapropriação: entidades públicas; concessionários comuns e especiais (parceiros privados em PPPs), permissionários, arrendatários e autorizatários ${ }^{8}$; entidades que exercessem funções delegadas do Poder Público; e, por fim, empreiteiras contratadas para a realização de obras públicas.

A reedição da medida parece bastante salutar, uma vez que permitiria que o Poder Público transferisse ao contratado para realizar obras públicas, na forma de empreitada regida pela Lei no $8.666 / 93$ ou contratação integrada disciplinada pelo Regime Diferenciado de Contratações (Lei no 12.462/2011), não apenas a responsabilidade por distribuir e acompanhar essas demandas, como também pelo pagamento das indenizações devidas aos expropriados.

Ademais, a MP 700 exigia que o edital da licitação para a seleção da empreiteira responsável pela execução do projeto previsse o responsável por cada fase do procedimento de desapropriação, o orçamento estimado para a sua realização e a distribuição objetiva dos riscos entre as partes, incluído o risco pela variação do custo das desapropriações em relação ao orçamento estimado. A importância de o instrumento convocatório delimitar qual das partes será responsável por cada fase do processo expropriatório e trazer o orçamento estimado para as desapropriações reside justamente em trazer maior transparência para o procedimento, possibilitando que os licitantes formulem suas propostas a partir de regras claras, que Ihes permitam definir, ainda durante o certame, quais serão as atribuições - e os custos inerentes à sua realização - do futuro contratado.

8 Neologismo não encontrado no Vocabulário Ortográfico da Língua Portuguesa, da Academia Brasileira de Letras. Utilizado para se diferenciar do termo "permissionário", visto que uma permissão necessita de licitação, enquanto uma autorização não necessita, obrigatoriamente, de uma licitação. Disponível em: <http://www.taxinforme.com.br/porque-autorizatario-ao-inves-depermissionario/>. Acesso em: 03.08.2017.

Revista Publicum

Rio de Janeiro, v. 3, n. 2, 2017, p. 134-165

http://www.e-publicacoes.uerj.br/index.php/publicum

DOI: 10.12957/publicum.2017.29000 
Já a distribuição dos riscos ligados às expropriações, sobretudo o da variação dos valores inicialmente estimados, é de bom alvitre para que o contratado, ao assumir a responsabilidade pelo pagamento das indenizações, não seja desproporcionalmente onerado com flutuações no orçamento previsto para as desapropriações, seja em razão de erro por parte da Administração, quando do levantamento desse montante, seja devido às variações naturais do mercado imobiliário no curso do tempo. Assim, se, porventura, os custos com as desapropriações superarem as quantias previstas no edital, caberá à Administração contratante o dever de recompor o equilíbrio econômico-financeiro do contrato, assegurando ao contratado o direito de revisão dos montantes repassados pelo Poder Público.

Essa divisão de riscos deve ser desenhada de modo a produzir incentivos para que a Administração faça um trabalho apurado na estimativa dos custos com desapropriações, a fim de evitar tanto um subdimensionamento quanto um superdimensionamento desses valores - que costumam ser bastante relevantes em relação ao custo final do projeto.

O subdimensionamento, de um lado, é prejudicial porque aumenta o risco de seleção adversa, na medida em que os licitantes, justamente por saberem que terão direito de pleitear o reequilíbrio contratual caso despendam mais do que a quantia estimada com as desapropriações, valem-se desses erros de cálculo do Poder Público para apresentar propostas sabidamente inexequíveis e vencer artificialmente o certame - logo em seguida cobrando a diferença em sucessivos pleitos de revisão contratual. Já o superdimensionamento dos custos com desapropriações, por outro lado, gera um encarecimento desnecessário do projeto, tendo em vista que os licitantes embutirão esses valores em suas propostas e, na fase de execução contratual, quando a quantia se mostrar exagerada, não devolverão valores recebidos do Poder Público.

Mauricio Portugal Ribeiro ${ }^{9}$ defende que essa divisão de riscos deveria ser feita de maneira estanque a partir dos valores estimados, da seguinte forma: se os gastos do contratado com o pagamento de indenizações em desapropriações excederem o montante estimado, ele fará jus à revisão do contrato; já se o valor despendido for inferior à quantia estimada, o contratado poderá embolsar essa diferença. Para o autor, essa solução geraria maior incentivo para que o contratado buscasse negociar com os expropriados de maneira mais eficiente e, ainda, estimularia o Poder Público a ser o mais

\footnotetext{
${ }^{9}$ RIBEIRO, Mauricio Portugal. Desapropriações e desocupações em concessões e PPPs: custos, riscos, sensibilidade política e os Princípios do Equador. Disponível em: $<$ http://www.slideshare.net/portugalribeiro/desapropriao-e-reassentamento-final-parapublicacao>. Acesso em: 08.08.2017.

Revista Publicum

Rio de Janeiro, v. 3, n. 2, 2017, p. 134-165

http://www.e-publicacoes.uerj.br/index.php/publicum

DOI: 10.12957/publicum.2017.29000
} 
criterioso possível na avaliação desses custos, a fim de evitar o desperdício de recursos públicos.

Além disso, destaca Portugal que, mesmo quando o contratado tem direito de pleitear a revisão do contrato, essa recomposição do equilíbrio econômico-financeiro não é imediata e nem sempre paga em pecúnia, sendo frequentes as recomposições feitas por meio de prorrogações de concessões ou readequação do prazo para entrega da obra ou do cronograma de investimentos que o particular deverá realizar. Assim, mesmo nesses casos, o contratado continuaria tendo estímulo para formular propostas de valores necessários ao custeio das desapropriações e remoções compatíveis com a realidade de mercado, considerando que propostas subdimensionadas inevitavelmente implicariam prejuízos, os quais seriam apenas parcialmente mitigados pela revisão contratual.

Em que pese o acerto dos comentários do autor a respeito da demora na tramitação de processos de reequilíbrio de contratos administrativos, deve-se destacar que o particular responsável pela construção (e, no caso de concessões, operação) de grandes empreendimentos não é hipossuficiente frente ao Poder Público; amiúde este dispõe de mais informações técnicas sobre o projeto do que a própria Administração e essa assimetria de informações pode funcionar como um fator de desequilíbrio em favor do contratado em processos de revisão de contratos administrativos.

Dessa forma, propomos aqui que, em vez de o contratado ter um direito automático à revisão do contrato na hipótese de os gastos com as indenizações excederem o montante estimado à época da contratação, o particular fique obrigado a demonstrar em seu pleito as razões que levaram a essa diferença, somente fazendo jus ao reequilíbrio contratual se ficar demonstrado que não houve erros nem subdimensionamento na estimativa inicial, e que a variação decorreu de fatores não controláveis pelas partes - como, por exemplo, uma inflação acima do previsto para o período ou uma valorização imobiliária extraordinária na localidade.

Ainda no que se refere à repartição dos riscos ligados às desapropriações e remoções, dois eventos podem impactar sensivelmente no custo final com essa etapa: (i) a metodologia escolhida para as avaliações dos imóveis afetados; e (ii) a variação dos preços dos imóveis desde o início dos estudos de viabilidade até a conclusão de todas as realocações.

Em relação à metodologia para a realização das avaliações dos imóveis atingidos, cabe notar que a NBR № 14563/2001 estabelece normas técnicas para a avaliação de bens, funcionando como um relevante parâmetro para mitigar riscos de super e 
subdimensionamento dos valores a serem despendidos com as indenizações devidas em processos de expropriação ${ }^{10}$.

Já no que tange à variação dos dispêndios com as indenizações, deve-se ter em mente que, quanto maior a demora na conclusão das expropriações, maiores as chances de o custo inicialmente estimado restar profundamente alterado ao final do projeto e é comum que os editais de licitação atribuam o ônus por esse evento ao contratado.

Além disso, a demora na conclusão das expropriações faz com que os proprietários e/ou ocupantes remanescentes aumentem seu poder de barganha sobre a Administração (situação descrita na literatura estrangeira como holdout problem ${ }^{11}$ ), na medida em que, muitas vezes, há prazo para a conclusão do projeto e a obra já se iniciou nas parcelas do terreno que se encontram liberadas, o que pode aumentar ainda mais os custos com remoções e desapropriações.

Portugal critica esse sistema de atribuição dos riscos de variação do preço dos imóveis integralmente para o particular, afirmando que há uma transferência de riscos muito grande para o concessionário sem que ele possa controlá-los e que, mesmo quando o risco de variação nas estimativas com a desapropriação não é transferido para o concessionário, ele continua tendo incentivo para não ultrapassar esse orçamento, uma vez que os reequilíbrios contratuais tomam tempo e dificilmente são feitos em dinheiro, como visto. Por outro lado, Mario Engler sugere que parte do risco de variação seja alocado junto ao particular, de modo aumentar seu incentivo para reduzir custos de desapropriação ${ }^{12}$.

10 No entanto, a norma não soluciona todas as questões que podem surgir nesse momento de avaliação dos bens atingidos pelo projeto, principalmente no que diz respeito ao cômputo (ou não) da valorização que o imóvel irá sofrer após a conclusão das obras, no montante da compensação a ser paga ao proprietário. Neste ponto, pensamos que a valorização futura não deve ser considerada na indenização devida, uma vez que (i) apenas após a conclusão do projeto é que é possível calcular a valorização efetivamente ocorrida; e (ii) no ordenamento pátrio, o DL 3.365/41 prevê, em seu art. 26, que o valor da indenização será contemporâneo à avaliação.

11 Sob a ótica da eficiência econômica, não se pode permitir que um único ou um pequeno grupo de particulares inviabilize a implantação do empreendimento por meio de uma injusta resistência ao projeto, situação apresentada no jargão econômico como holdout problem. A possibilidade de a Administração, ao final das negociações, desapropriar o bem ainda que contrariamente à vontade do expropriado visa a evitar esse problema; no entanto, à luz dos novos paradigmas do Direito Administrativo - próprios de uma filtragem constitucional do ordenamento - a autoexecutoriedade do ato administrativo não deve acarretar arbitrariedades por parte do Poder Público, demandando motivação quanto ao bem escolhido e a apuração de justa indenização. Para um aprofundamento sobre o holdout problem em desapropriações, vide: ACOCELLA, Jéssica. Uma releitura da Desapropriação à Luz da Constituição de 1988 e suas Principais Repercussões sobre o Regime Jurídico Vigente. 2013. Dissertação (Mestrado em Direito Público) - Universidade do Estado do Rio de Janeiro, Rio de Janeiro, 2013. P. 102-107.

12 RIBEIRO, Mauricio Portugal. Op. Cit.

Revista Publicum

Rio de Janeiro, v. 3, n. 2, 2017, p. 134-165

http://www.e-publicacoes.uerj.br/index.php/publicum

DOI: 10.12957/publicum.2017.29000 
Embora seja verdadeira a afirmação de que o concessionário não controla os riscos de variação dos imóveis, a Administração também não é capaz de gerenciá-los e, como agravante, costuma ser ainda mais lenta para concluir os processos de remoções e desapropriações, como o próprio autor destaca. Logo, atribuir esses riscos integralmente à Administração apenas maximiza a chance de eles se materializarem. Parece, assim, mais eficiente que eles sejam repartidos entre as partes, tal como preveem os editais da Linha 6 do metrô de São Paulo e da construção e concessão da ferrovia Porto do Conde Açailândia ${ }^{13}$.

Além disso, é recomendável que, nessa repartição de riscos, seja atribuído um prazo para que a Administração publique os respectivos decretos expropriatórios e para que o particular, após essa publicação, ajuíze as respectivas ações de desapropriação e/ou promova as ações de reintegração de posse, a fim de evitar que o custo com as desapropriações e remoções varie em razão de atraso no início da execução do projeto.

\subsection{A desapropriação por zona como instrumento de remuneração de parceiros privados e concessionários}

Passando à análise da segunda medida que consideramos capaz de incrementar as expropriações ligadas a projetos de infraestrutura (qual seja, a utilização da desapropriação por zona como mecanismo de remuneração do parceiro privado/concessionário), destacamos, nesse tocante, que a desapropriação por zona poderia funcionar como um importante mecanismo de diversificação da contraprestação paga pela Administração ao parceiro privado em contratos de concessão e PPP, evitando, inclusive, que esses aportes públicos demandem a alocação direta de verbas orçamentárias - especialmente escassas nos últimos tempos.

A desapropriação por zona está prevista no art. 4ㅇ do DL 3.365/41, que conta com disposição especial para as Parcerias Público-Privadas em seu parágrafo único do mesmo artigo, permitindo que o Poder Público ou o parceiro privado desaproprie não só a área que será utilizada para a realização da obra, mas também as do entorno que venham a ser valorizadas em decorrência da obra pública que será desenvolvida no local (e que motivou

${ }^{13}$ Op. Cit: Linha 6 metrô 6 SP: concessionário arca com variação de 10\% para mais ou para cima na estimativa de custos das desapropriações. Por outro lado, condiciona a aplicação desta divisão de riscos à realização das desapropriações na via judicial. Ferrovia Porto da Vila do Conde - Açailândia (modelo piloto para o PIL federal): concessionário arcaria com $50 \%$ do excedente do valor estimado. Com isso, busca-se um incentivo para que o concessionário reduza os custos com as desapropriações e, ao mesmo tempo, possa ficar com as diferenças para baixo que consiga economizar. 
as próprias desapropriações). Conforme estabelece o Decreto-Lei, se o Poder Público justificadamente estender a obra, explicitando os motivos da extensão, as zonas vizinhas poderão ser incluídas na área abrangida pela expropriação, desde que, na declaração de utilidade pública, esteja discriminado que uma parte da desapropriação será feita para a obra, e outra, exclusivamente, por zona.

Há, contudo, uma segunda possibilidade de desapropriação por zona (e é nela que recai a presente análise): hipóteses em que o Estado vislumbrar que a obra a ser executada gerará uma supervalorização dos terrenos vizinhos. Neste caso, o Estado ou o parceiro privado pode desapropriar por zona esta região que será objeto de extraordinária valorização, destinando tais espaços à revenda tão logo esta se concretize e, assim, utilizando o montante recebido com a revenda para se remunerar pelos gastos que teve com a obra.

Alguns doutrinadores ${ }^{14}$ entendiam que essa desapropriação não tinha sido recepcionada pela $\mathrm{CRFB} / 88$. Primeiro, porque se trataria de uma especulação imobiliária. Segundo, porque a CRFB/88 definiu que, quando uma obra gerasse benefícios a terrenos vizinhos, poderia ser instituída uma contribuição de melhoria (espécie tributária) para equacionar a situação, de modo a evitar enriquecimento sem causa dos proprietários vizinhos à obra e ressarcir a Administração dos custos do empreendimento ${ }^{15}$. O STF, entretanto, manteve, mesmo na nova ordem constitucional, o entendimento firmado desde o RE $82.300^{16}$, decidindo pela constitucionalidade da desapropriação por zona tanto nos casos de necessidade de posterior extensão da obra quanto nas hipóteses de supervalorização extraordinária dos terrenos vizinhos.

A Suprema Corte brasileira esclareceu, ainda, que a supervalorização dos terrenos vizinhos pode ser ordinária ou extraordinária. A ordinária ocorreria quando todos os terrenos valorizassem (aproximadamente) no mesmo padrão, e, então, uma contribuição de melhoria com alíquota fixa resolveria a situação. Já na supervalorização extraordinária ou seja, quando um terreno valorizasse muito mais do que outro -, embora fosse possível a instituição de contribuição de melhoria com alíquotas variáveis, neste caso, a forma

14 Vide: MELLO, Celso Antônio Bandeira de. Curso de Direito Administrativo. 26ạ ed. São Paulo: Malheiros Editores, 2009, p. 881.

15 Aqui, pode-se debater acerca da possibilidade de instituição de contribuição de melhoria nos casos de obra que gere comodidade para a coletividade como um todo, mas acarrete desvalorização dos imóveis situados em seu entorno, tal qual costuma ocorrer quando da construção de viadutos e outros equipamentos urbanos que trazem impactos positivos para a mobilidade urbana, mas comprometem a harmonia estética da vizinhança.

${ }^{16}$ STF, RE 82.300/SP, Rel. Min. Rodrigues Alckmin, DJ 09 jun. 1978: referente ao caso da construção das estações Santana e Jabaquara do Metrô de São Paulo, em cuja oportunidade a Empresa Municipal de Urbanização - Emurb - pretendeu desapropriar por zona algumas áreas vizinhas, para posterior revenda e compensação dos gastos com a obra. 
mais adequada e eficiente de garantir a remuneração do Poder Público ou do parceiro privado, concernente ao que ele gastou com a obra, seria a desapropriação por zona.

Nessa esteira, ainda nos dias atuais, a jurisprudência do STJ ${ }^{17}$ considera constitucional a desapropriação por zona, de modo que ela se tornou um instrumento de grande interesse público para a coletividade, visando à recuperação dos gastos efetuados na execução de planos de urbanização e possibilitando que o Estado promova a solução de maior eficiência econômica, que dispensa - ou, ao menos, reduz - a alocação de recursos orçamentários na contraprestação pública envolvida nas PPPs.

Cabe destacar, ainda, que, muito embora a literalidade do parágrafo único, do art. 4o do DL 3.365/41 mencione a utilização do instituto apenas para as PPPs, a desapropriação por zona poderia ser, igualmente, manejada nas concessões comuns, regidas pela Lei no 8.987/1995. Como ensina a teoria do microssistema das concessões, as disposições relativas às concessões aplicam-se igualmente às PPPs (que nada mais são do que concessões especiais) e vice-versa ${ }^{18}$. Assim, nas concessões comuns, a receita arrecadada pelo concessionário na revenda das áreas alcançadas pela valorização extraordinária poderia ser contabilizada no instrumento contratual a título de receita alternativa, inclusive para fins de preservação da modicidade tarifária, nos moldes do art. 11 da Lei no 8.987/1995.

O aspecto negativo da desapropriação por zona, por outro lado, gira em torno de uma eventual expulsão das pessoas carentes dessas áreas desapropriadas, forçando-as a ocuparem áreas mais distantes e frequentemente com menos disponibilidade de serviços, para darem lugar àqueles que detenham a superioridade de poder aquisitivo, fenômeno conhecido como "gentrificação" (tradução neologística da palavra gentrification, originária da língua inglesa).

Uma solução para mitigar esse problema seria o estabelecimento, no próprio contrato de concessão ou PPP e no processo expropriatório, de uma obrigação de que sejam destinados espaços para a construção de moradias populares na área expropriada, evitando que toda a zona vizinha à obra se destine exclusivamente ao acolhimento de pessoas de poder aquisitivo mais elevado. Essa obrigação de reserva de espaço para a

17 STJ, REsp 795.580/SC, Rel. Min. Castro Meira, 2a Turma, DJ 12/12/2006.

18 Grosso modo, de acordo com as lições de Natalino Irti no clássico L'età della codificazione, um microssistema se forma quando um determinado assunto é disciplinado por uma série de normas especiais, de igual hierarquia, que se aplicam reciprocamente, sem que uma seja superior à outra, a partir de princípios setoriais próprios daquele instituto. Para maiores considerações teóricas sobre o tema, vide: ARAGÃO, Alexandre Santos de. Teorias pluralistas das fontes de direito: lex mercatoria, ordenamentos setoriais, subsistemas, microssistemas jurídicos e redes normativas.. Revista Trimestral de Direito Civil, v. 36, p. 3-36, 2008.

Revista Publicum

Rio de Janeiro, v. 3, n. 2, 2017, p. 134-165

http://www.e-publicacoes.uerj.br/index.php/publicum

DOI: 10.12957/publicum.2017.29000 
construção de moradias populares seria aplicada tanto no caso de o próprio concessionário/parceiro privado edificar a área expropriada por zona antes da revenda quanto na hipótese de a área ser revendida ainda sem construções para uma incorporadora, situação em que a aprovação de futuro loteamento pela adquirente ficaria sujeito à comprovação do cumprimento da reserva de espaços populares e da ausência de discriminação desses moradores nos projetos $^{19}$.

Assim, proporcionalmente, o princípio da eficiência econômica estaria sendo atendido, ao mesmo tempo em que o aspecto social do projeto também estaria presente, de forma que a restrição ao direito de habitação levada a efeito pela desapropriação por zona fosse compensada com a realocação de ao menos parte dos indivíduos removidos nas proximidades ou em lugares que não prejudicassem, na medida do possível, o seu estilo de vida e as suas práticas culturais.

\section{Desapropriações e remoções: para além da judicialização}

\subsection{Maior proteção aos envolvidos nos processos de remoções e desocupações}

Dando início ao estudo das duas medidas que podem incrementar a eficiência das desapropriações em geral - embora nos pareçam especialmente caras às expropriações envolvendo a implantação de projetos de infraestrutura, haja vista a relevância desses processos para o sucesso do empreendimento -, analisaremos primeiramente a necessidade de fixação de um sistema mais eficiente para a proteção de possuidores desalojados em processos expropriatórios, passando, em seguida, ao estudo das desapropriações e remoções amigáveis.

Em um ponto que demanda resgate urgente, a MP 700 tentava suprir a lacuna legal de proteção aos possuidores, trazendo uma maior preocupação com a população carente, em geral em situação de ocupação irregular, que pode vir a ser removida em razão da implantação do projeto.

A redação originária do DL 3.365/41, claramente voltada para os proprietários munidos de justo título - e novamente em vigor, com o término da vigência da MP 700/2015 sem que tenha sido convertida em lei -, nada dispõe a respeito dos

19 A experiência do direito comparado demonstra a importância do não estabelecimento de discriminações para os moradores de menor poder aquisitivo: em Nova York, projetos de habitação construídos com reserva de apartamentos populares foram erguidos com uma polêmica "porta dos fundos" para o acesso desses moradores. Vide: <http://oglobo.globo.com/economia/em-nova-yorkse-voce-ganha-pouco-entre-pela-porta-dos-fundos-15384556>. Acesso em: 07.12.2016.

Revista Publicum

Rio de Janeiro, v. 3, n. 2, 2017, p. 134-165

http://www.e-publicacoes.uerj.br/index.php/publicum

DOI: $10.12957 /$ publicum.2017.29000 
desalojamentos que podem ocorrer durante a execução da obra, não trazendo nenhum mecanismo de proteção a essas pessoas em situação de vulnerabilidade social. Como visto, prevê o DL 3.365/41 que as outras discussões, que não envolvam o valor da indenização a ser paga ao proprietário ou vícios processuais, devem ser tratadas em ação própria, deixando claro que a presença de eventuais ocupantes no imóvel expropriado não será debatida na desapropriação - nem, muito menos, serviria de empecilho a seu deslinde.

A MP 700 buscava minimizar essa lacuna ao acrescentar o art. 40-A ao DL 3.365/41, segundo o qual quando o imóvel a ser desapropriado estivesse ocupado coletivamente por assentamentos sujeitos à regularização fundiária de interesse social, o ente expropriante deveria prever medidas compensatórias no planejamento da ação de desapropriação. $O \S 2^{\circ}$ do dispositivo, por sua vez, trazia um rol exemplificativo das medidas compensatórias que poderiam ser adotadas, enumerando expressamente a realocação de famílias em outra unidade habitacional, a indenização de benfeitorias ou a compensação financeira suficiente para assegurar o restabelecimento da família em outro local, mediante prévio cadastramento dos ocupantes.

Ainda que a MP 700 tenha perdido sua vigência, é comum, na prática, que a implantação de projetos de infraestrutura envolva instrumentos de proteção às famílias residentes em áreas que serão atingidas pelo projeto, mesmo que não disponham de justo título. Isso ocorre devido à crescente organização e mobilização não só dos atingidos, mas também da própria sociedade civil em torno de demandas relativas ao direito à moradia, o que faz com que a remoção de pessoas carentes do local onde residem sem nenhuma espécie de tutela estatal gere atrasos no projeto e, ainda, exponha o gestor público a elevado risco político.

Assim, é comum que a proteção às famílias desalojadas pelo projeto se dê de três formas possíveis: realocação em outra unidade habitacional, indenização da benfeitoria (já que a família não é proprietária do solo, mas tão-somente da construção) e compensação financeira. A realocação da família em unidade habitacional usualmente se faz por meio de sua inclusão em programas de habitação popular, tal como o "Minha Casa Minha Vida", criado pelo Governo Federal e executado em parceria com Estados e Municípios. Já a indenização da benfeitoria permite que os ocupantes sejam indenizados com base no valor da construção onde residiam, tendo em vista que o fato de não serem proprietários do terreno impede uma indenização pela perda da propriedade. Por sua vez, a compensação financeira, chamada no jargão prático de "aluguel social", costuma ser feita 
mediante pagamentos mensais creditados em conta bancária mantida pelos beneficiários para esta finalidade em instituição financeira oficial.

O "aluguel social", embora amplamente difundido (provavelmente por ser a medida de mais fácil execução), apresenta algumas fragilidades. A uma, porque podem ocorrer falhas no cadastramento, ensejando pagamentos em duplicidade a membros da mesma família, deixando de fora famílias que residiam na localidade ou incluindo núcleos que, na verdade, encontravam-se assentados em outra localidade. A duas, porque o controle do uso dos valores recebidos pelas famílias é muito difícil na prática, de modo que, mesmo o pagamento tempestivo do benefício, não garante que a família utilizará essa quantia no custeio de nova residência em local seguro. A três, porque o montante pago a título de aluguel social costuma orbitar na faixa dos $R \$ 400$ a $500,00^{20}$, valor que dificilmente se mostra suficiente para o custeio de uma moradia segura nos grandes centros do Brasil, muitas vezes obrigando a família a se restabelecer em local de risco e/ou irregular.

A indenização da benfeitoria, por sua vez, poucas vezes consegue permitir que a família adquira um terreno e construa nova residência em área regularizada, uma vez que a reparação abrange apenas o valor da construção (já que a família não é dona do terreno) e esta frequentemente tem uma estrutura simples, além de se localizar em área pouco valorizada. Com isso, o montante que a família recebe, na maioria das vezes, apenas é suficiente para adquirir outra residência situada em área igualmente de risco, apenas deslocando o risco social para outra localidade.

Nesse sentido, a solução de reassentamento da família em outra unidade habitacional parece ser a mais definitiva e a única, dentre aquelas acima tratadas, capaz de efetivamente reduzir o déficit habitacional no Brasil e todos os problemas que este traz a reboque, como a ausência de infraestrutura básica e a falta de acesso à saúde e ao saneamento básico. Por outro lado, além dos custos econômicos envolvidos na sua implementação, é frequente que a efetiva entrega dessas residências demore meses ou até anos, expondo as famílias que aguardam por essa entrega às inseguranças do aluguel social até que, de fato, recebam as novas casas.

Para minimizar esse problema, seria interessante que os editais de licitação do empreendimento já previssem como uma das obrigações do futuro contratado/delegatário a necessidade de construção de habitações populares para abrigar os desalojados em decorrência da implantação do projeto de infraestrutura, atribuindo o

20 Valores pagos pelo Estado do Rio de Janeiro a depender do Município onde se a família reside, na forma dos Decretos Estaduais no 42.406/2010 e 43.091/2011.

Revista Publicum

Rio de Janeiro, v. 3, n. 2, 2017, p. 134-165

http://www.e-publicacoes.uerj.br/index.php/publicum

DOI: 10.12957/publicum.2017.29000 
risco de demora na entrega das unidades ao particular, de modo que este fique obrigado a suportar o pagamento de aluguel social no caso de atraso no cronograma das obras. Durante o cronograma estabelecido para a obra, o custeio desse auxílio-moradia seria feito pela própria Administração, dona da obra, mas, na hipótese de eventual atraso na entrega das unidades, os pagamentos passariam a ser suportados pelo particular contratado, gerando incentivo para que este apresente um cronograma exequível e se atenha a ele.

Ademais, seria interessante que os projetos de reassentamento contemplassem também espaços para a implantação de pequenos estabelecimentos comerciais, a serem explorados pelos próprios moradores da região. Com isso, além de gerar emprego e renda na comunidade, permite-se que famílias de já desenvolviam atividades comerciais nos imóveis expropriados (muitas vezes utilizados com finalidade mista de comércio e moradia) possam permanecer exercendo suas atividades laborais.

Outra recomendação importante é que, no momento do cadastramento das famílias a serem removidas, é recomendável que estas sejam plenamente informadas - e formalizem um compromisso por escrito - de que receberão o aluguel social apenas até o recebimento definitivo das moradias a elas destinadas, sendo excluídas do benefício provisório em caso de recusa infundada da unidade habitacional. A medida tem por objetivo evitar que a família recuse o recebimento de nova moradia com o propósito de continuar recebendo indefinidamente o aluguel social, benefício de natureza pecuniária, cuja forma de emprego - repita-se - comumente não é objeto da devida fiscalização.

Vale notar que o modelo de embutir, no próprio contrato de obra/concessão da infraestrutura, a obrigação de construção de moradias para os atingidos pelo projeto, ao contrário do que pode parecer à primeira vista, não encarece o projeto final. $\mathrm{O}$ risco político de se implantar um projeto de infraestrutura sem este cuidado de realocar os atingidos, na prática, tornaria o empreendimento inviável; assim, o custo com a construção das moradias ou outra medida de reassentamento de desalojados já seria, de qualquer maneira, suportado pelo Poder Público, apenas com a diferença de que seria realizado um certame apartado para a escolha da empresa responsável por esta construção.

Ainda que, na prática, as remoções no Brasil tenham contado com mecanismos de proteção aos indivíduos afetados pelo projeto, a falta de normatização sobre o tema traz uma insegurança jurídica indesejável, na medida em que não há nenhum dispositivo legal que, de fato, obrigue os gestores a seguirem os procedimentos ora narrados - cuja adesão voluntária por parte das autoridades responsáveis pelo projeto, até o momento, pode ser 
explicada mais por razões ligadas à Teoria da Public Choice ${ }^{21}$ do que a uma efetiva preocupação humanitária.

Nesse sentido, é premente a necessidade de que a legislação brasileira passe a exigir expressamente a adoção de mecanismos de proteção às pessoas removidas em processos de desapropriação e reintegração de posse, a partir de critérios efetivos e, ao mesmo tempo, viáveis.

Os Princípios do Equador podem funcionar como inspiração para essa legislação, constando dentre suas previsões para o reassentamento das pessoas removidas: (i) realocação preferencialmente em áreas regularizadas, admitindo a indenização das benfeitorias em dinheiro apenas no caso de a própria pessoa desalojada assim preferir; (ii) disponibilização de auxílio para a integração social e econômica das pessoas realocadas nas comunidades anfitriãs; (iii) apoio às comunidades anfitriãs para que possam receber esses indivíduos; e (iv) apresentação de cronograma de implantação do projeto de infraestrutura compatível com o de reassentamentos.

Ademais, os Princípios contemplam as seguintes diretrizes: (i) prevalência da regra mais benéfica para a população afetada em caso de conflito entre regras locais e os princípios; (ii) isonomia, clareza, transparência e razoabilidade nos critérios de elegibilidade de pessoas afetadas a benefícios e mecanismos de compensação; (iii) garantia de que toda pessoa afetada pelo projeto seja informada de maneira clara, oportuna e correta; (iv) disponibilização de mecanismos de participação das pessoas afetadas no projeto no processo de seu planejamento, implantação e monitoramento; (v) assistência e suporte a essas pessoas, com atenção especial àquelas em situação de maior vulnerabilidade; (vi) prioridade para aquisições amigáveis, reduzindo-se ao mínimo possível a utilização de mecanismos litigiosos.

Não obstante a maior rede de proteção oferecida pelos Princípios do Equador àquelas pessoas afetadas pelo projeto, a sua adoção integral, na prática, pode levar ao encarecimento do projeto. Com isso, é recomendável que os estudos de viabilidade prévios à modelagem do projeto de infraestrutura contemplem os dispêndios estimados para se seguir tanto os Princípios do Equador quanto apenas a legislação nacional sobre o

${ }^{21}$ A Teoria da Public Choice, desenvolvida pela Escola de Chicago, defende a ideia de que agentes econômicos - inclusive autoridades e políticos -, de modo geral, atuam visando à maximização de seus próprios interesses, e não à consecução do interesse coletivo. No caso de agentes políticos, suas ações seriam movidas pelo interesse pessoal de manter altos índices de popularidade que lhes garantam a permanência no poder - e não promover o bem-estar coletivo. Para maiores considerações, vide: BUCHANAN, James M.; TULLOCK, Gordon. The Calculus of Consent: Logical Foundations of Constitutional Democracy. Ann Arbor: University of Michigan Press, 1962 E: Rowley, Charles K., and Friedrich Schneider, eds. The Encyclopedia of Public Choice. 2 vols. Boston: Kluwer, 2004. 
tema das remoções e desocupações - que, em geral, são abordadas a partir da lógica da mera reintegração de posse. Dessa forma, é possível subsidiar o gestor público para que possa optar por um dos dois modelos, levando em consideração, de um lado, a diminuição dos custos de transação operada pela adoção dos Princípios do Equador ${ }^{22}$, e, de outro, o possível encarecimento do projeto que esta pode acarretar.

Recomendamos, contudo, seja dada preferência à adoção dos Princípios do Equador sempre que esta se mostrar possível. A uma, porque, como visto, a baixa proteção oferecida pelo ordenamento brasileiro a ocupantes e possuidores acaba por gerar altos custos de transação para a efetivação de processos de reintegração de posse, uma vez que esses possuidores frequentemente resistem à pretensão possessória. Essa realidade acaba por tornar esses procedimentos custosos e demorados para o proprietário, além de representarem um elevado custo político para o gestor público. A duas, porque, os maiores repassadores (Itaú, Santander, Banco do Brasil e Bradesco) de recursos para o Banco Nacional de Desenvolvimento Social - BNDES - principal financiador de projetos de infraestrutura do país - são signatários dos Princípios do Equador $^{23}$, o que os obriga a seguir suas diretrizes para a outorga de financiamentos bancários ${ }^{24}$.

No Estado do Rio de Janeiro, foi editado um Decreto (Decreto no 43.415/2012) para regular a questão das remoções, com a intenção de que os procedimentos da Administração Pública Estadual para a desocupação dessas áreas fossem uniformizados, e, ainda, de garantir maior proteção às pessoas atingidas pelo processo. De acordo com a norma em comento, o processo de reassentamento tem a orientação de (i) atingir o menor número possível de unidades para demolição, privilegiando os espaços livres no próprio local e, na inexistência destes, a escolha de terrenos nas proximidades; e (ii) adotar soluções consensuais, com a participação da população afetada em todas as etapas do processo e indicação de alternativas para a realocação, de forma a buscar a melhoria das condições de habitabilidade, e a respeitar as especificidades de cada família.

\footnotetext{
22 Os custos de transação de uma operação referem-se aos custos de negociação e conclusão de uma determinada transação. Para maiores informações sobre a Teoria dos Custos de Transação, vide: COASE, Ronald Henry. The nature of the firm. Economica, v. 4, p. 386-405, 1937. The nature of the firm: meaning. In: WILLIAMSON, O. E.; WINTER, S. G. (Eds.). The nature of the firm: origins, evolution and development. Oxford: Oxford University Press, 1991. p. 48-60.

23 Possivelmente, a partir de uma lógica típica da Public Choice de que a adoção dos Princípios do Equador encarece os custos finais do projeto e, consequentemente, amplia o valor do financiamento necessário à sua realização.

24 RIBEIRO, Mauricio Portugal. Desapropriações e desocupações em concessões e PPPs: custos, riscos, sensibilidade política e os Princípios do Equador. Disponível em: $<$ http://www.slideshare.net/portugalribeiro/desapropriao-e-reassentamento-final-parapublicacao $\geq$. 
As alternativas para a realocação definitiva dos envolvidos são as seguintes: (i) construção de nova moradia no local, conforme previsão do Programa "Minha Casa Minha Vida", ou empreendimento similar, ou mesmo do próprio projeto; (ii) pagamento de indenização pela acessão - o Decreto 43.415/12 faz uso da expressão "benfeitoria", porém, como bem destaca Maurício Portugal Ribeiro ${ }^{25}$, pelo art. 1.255 do Código Civil, a construção seria equivalente a uma acessão -, cujo valor de avaliação, estipulado em tabela no próprio Decreto, poderá ser acrescido em até $80 \%$, havendo insuficiência na acessibilidade aos serviços, ou diminuído em até 50\%, decorrente de depreciação; (iii) a chamada "compra assistida", que consiste na compra de uma nova moradia, preferencialmente, próxima à comunidade e em área que não gere riscos à família, com valor baseado na que será demolida.

Ainda de acordo com o Decreto Estadual, o aluguel mensal provisório ("aluguel social") será pago até o reassentamento definitivo, podendo ser concedido nas hipóteses em que não forem aplicadas a construção de nova moradia no local, a indenização da acessão, ou a compra de uma nova moradia, a critério da Administração Pública, justificadamente.

Já sobre o reassentamento, uma recomendação (inclusive constante do Decreto) é que o contratado busque um diálogo com as famílias, de modo que o projeto e a localização dos novos assentamentos atenda - na medida das possibilidades reais e orçamentárias - às demandas das famílias, devendo-se dar preferência à realocação em localidade próxima àquela onde os atingidos pelo projeto já residiam ou, na impossibilidade desta, em local de fácil acesso e com oferta satisfatória de serviços públicos.

Com isso, busca-se atribuir maior legitimidade à ação administrativa por meio da participação do administrado no processo de tomada de decisões, concretizando ideais de democracia deliberativa ${ }^{26}$ no processo de remoções, com a possibilidade de os

\footnotetext{
25 Op. Cit.

${ }^{26}$ BARROSO, Luís Roberto. A razão sem voto: o Supremo Tribunal Federal e o governo da maioria. Revista Brasileira de Políticas Públicas, Brasília, v. 5, Número Especial, 2015 p. 40-41: “Convém aprofundar um pouco mais esse último ponto. Em uma visão tradicional e puramente majoritária da democracia, ela se resumiria a uma legitimação eleitoral do poder. Por esse critério, o fascismo na Itália ou o nazismo na Alemanha poderiam ser vistos como democráticos, ao menos no momento em que se instalaram no poder e pelo período em que tiveram apoio da maioria da população. Aliás, por esse último critério, até mesmo o período Médici, no Brasil, passaria no teste. Não é uma boa tese. Além do momento da investidura, o poder se legitima, também, por suas ações e pelos fins visados. Cabe retomar a ideia de democracia deliberativa, que se funda, precisamente, em uma legitimação discursiva: as decisões políticas devem ser produzidas após debate público livre, amplo e aberto, ao fim do qual se forneçam as razões das opções feitas, por isso tem-se afirmado, anteriormente, que a democracia contemporânea é feita de votos e argumentos. Um insight
} 
administrados influenciarem direta e ativamente os processos decisórios do Poder Público. Essa maior consensualidade na definição do projeto final de reassentamentos, inclusive, reduz impasses que podem atrasar o cronograma de entrega da obra (como protestos e mobilizações das famílias desalojadas), o que vai ao encontro dos interesses do contratado num cenário em que ele responde pelo aluguel social devido a partir de eventual atraso na entrega das unidades habitacionais.

Por outro lado, há de se destacar que a participação dos envolvidos não deve acarretar uma inviabilização do projeto, caso não se mostre possível atender integralmente aos pleitos dos moradores, sobretudo nos casos em que restar caracterizado um exercício abusivo do holdout. A consensualidade implica que tanto a população removida quanto a Administração e seus contratados e delegatários tentem chegar a uma solução mais equânime, que concilie da melhor forma possível os anseios dos envolvidos. Assim, se, por exemplo, não for possível a realocação em localidade próxima - reivindicação comum entre os removidos -, caberá ao responsável pela obra explicitar os motivos que tornam a medida inviável, bem como buscar concretizar pedidos alternativos desses moradores e assegurar que as moradias sejam construídas em local que disponha de acesso a serviços públicos.

É nítido que a materialização do processo que gera a extinção da propriedade sobre um bem ou direito pressupõe o atributo da autoexecutoriedade dos atos administrativos, o que, entretanto, não afasta a aplicação dos novos paradigmas do Direito Administrativo. Isto é, no processo de desapropriação, há de se levar em consideração tanto o incremento da ideia de consensualidade e de democratização da Administração Pública, quanto a exigência de motivação dos atos administrativos. Nesse sentido, quando o legislador constituinte previu a possibilidade de a Administração desapropriar bens privados, fez uma ponderação, no plano abstrato, em que o interesse

importante nesse domínio é fornecido pelo jusfilósofo alemão Robert Alexy, que se refere à corte constitucional como representante argumentativo da sociedade. Segundo ele, a única maneira de reconciliar a jurisdição constitucional com a democracia é concebê-la, também, como uma representação popular. Pessoas racionais são capazes de aceitar argumentos sólidos e corretos. 0 constitucionalismo democrático possui legitimação discursiva, que é projeto de institucionalização da razão e da correção".

No mesmo sentido: MOREIRA NETO, Diogo de Figueiredo. Teoria do poder: sistema de direito politico: estudo juspolítico do poder, Editora Revista dos Tribunais, São Paulo, 1992, p. 229-230: “a sociedade reage espontaneamente aos atos dos governantes, aprovando-os ou desaprovando-os; é um juízo de legitimidade de como estão utilizando os poderes que lhes forma confiados". Ademais, tratando da terceira modalidade da legitimidade do poder político, além da ordinária e da corrente, referida acima, o autor afirma: "Enquanto ligada ao resultado do exercício do poder, a legitimidade finalística depende totalmente do juízo do grupo sobre o desempenho do detentor do poder; se confirmou ou não, na prática do poder, aquilo que dele se esperava quando de sua investidura".

Revista Publicum

Rio de Janeiro, v. 3, n. 2, 2017, p. 134-165

http://www.e-publicacoes.uerj.br/index.php/publicum

DOI: 10.12957/publicum.2017.29000 
coletivo ganha peso, mas não aniquila o interesse privado, porque a desapropriação pressupõe prévia e justa indenização em dinheiro.

$\mathrm{Na}$ prática, porém, ainda são raros os casos em que vislumbramos essa preocupação da Administração em motivar o ato exproriatório e buscar um diálogo com o particular - o que reforça a importância de atualização da legislação que rege as desapropriações no Brasil, de modo a criar uma fase administrativa prévia ao ajuizamento de eventual ação, na qual a Administração seja obrigada a fornecer a exposição de motivos do ato e se abra a oportunidade de o particular impugná-lo quando entender que não estão presentes razões de interesse público que justifiquem a desapropriação ${ }^{27}$.

\subsection{Normatização e incentivos para a desapropriação amigável}

Na esteira da importância da busca pelo consenso em matéria de expropriações, chegamos à análise das desapropriações amigáveis, que ocorrem nos casos em que a Administração busca a aquisição consensual do bem necessário à implantação de determinado projeto ou desenvolvimento de determinada política pública. Nesses casos, o Poder Público, em vez de ajuizar a ação de desapropriação tão logo se declare a utilidade pública ou o interesse social sobre o bem, busca primeiramente chegar a um acordo com o proprietário, a fim de que essa aquisição seja feita de maneira amigável.

A desapropriação amigável nada mais é, portanto, do que uma operação de compra e venda, na qual o comprador é a Administração Pública, sendo o contrato assinado a partir de um consenso entre Poder Público e expropriado em relação ao valor devido, com o pagamento do preço em sede administrativa e o subsequente registro da escritura no cartório competente ${ }^{28}$.

\footnotetext{
27 No direito comparado, a Espanha conta com normas que obrigam, previamente ao início de processos expropriatórios, a instauração de um procedimento administrativo denominado Información Pública, em que quaisquer interessados dispõem de prazo para formular suas alegações, as quais devem ser consideradas pela Administração ao emitir decisão final fundamentada acerca da necessidade de desapropriação daquele(s) bem(ns) . (Vide: MORALES, María Luisa Martín. Necesidad de la ocupación de bienes o adquisición de derechos. In: OLVERA, Tomás Cobo (coord.). Los procedimientos administrativos expropiatórios: tutela frente a las actuaciones de la Administración. Barcelona: Editorial Bosch, 2011. p. 192 APUD Acocella, Jéssica, Op. Cit. P. 193). Já nos EUA, o Eminent Domain Procedure Act do Estado de Nova York (Article 2, Section 201) exige a realização de audiência pública em que a Administração ouça os afetados pelo projeto de modo a decidir quanto aos impactos sócio-ambientais da desapropriação. Legislação disponível em <http://law.onecle.com/new-york/eminent-domain-procedure/>. Acesso em 06.12.2016.

${ }^{28}$ Na definição de José dos Santos Carvalho Filho, "trata-se de negócio jurídico bilateral resultante de consenso entre as partes e retrata a vontade do proprietário, de alienar bem de sua propriedade a terceiro, e do adquirente, que por sua vez intenta transferir o bem a seu patrimônio. Esses elementos são exatamente os que compõem o contrato de compra e venda, não o desfigurando a
} 
Pode-se observar, de plano, que a desapropriação amigável apresenta vantagens tanto para o particular quanto para a Administração. Do lado do Poder Público, ela garante que o procedimento seja mais célere e menos custoso (já que não é necessário o ajuizamento de ação judicial com vistas a obter a propriedade do bem), permitindo o início do projeto muito antes do que ocorreria caso fosse necessário aguardar o cumprimento de mandado judicial de imissão provisória na posse - sobretudo nos casos em que há resistência do proprietário em deixar o imóvel ou naqueles em que o magistrado requer a realização de avaliação pericial previamente à decisão quanto ao pedido de imissão provisória.

Já em relação ao particular, a desapropriação amigável apresenta a considerável vantagem de que o pagamento da indenização será feito de maneira muito mais rápida, uma vez que feito em depósito em conta-corrente, cheque administrativo ou instrumento análogo de imediata liquidação, em contraposição ao pagamento por meio do moroso sistema de precatório próprio das liquidações realizadas judicialmente ${ }^{29}$. Além disso, o particular receberá de imediato a totalidade da indenização, afastando a aplicação da regra - de constitucionalidade bastante duvidosa ${ }^{30}$ - constante do art. 33 do DL 3.365/41, segundo a qual o expropriado, no momento da imissão provisória na posse, apenas pode

circunstância de ter havido anteriormente a declaração expropriatória. Note-se que nenhuma coerção é ainda imposta ao proprietário; a declaração não o obriga a celebrar ajuste com o Poder Público. Há, pois, interesse e livre manifestação de vontade por parte do proprietário. A despeito desses fatores, esse negócio jurídico bilateral tem sido denominado de desapropriação amigável" (CARVALHO FILHO, José dos Santos. Manual de Direito Administrativo. 15a ed. Rio de Janeiro: Lumen Juris, 2006, p. 687).

29 Trata-se, aqui, da mesma lógica do fundo garantidor de Parcerias Público-Privadas, em que, igualmente, a regra dos precatórios é afastada em razão de o pagamento não se dar em sede judicial, vejamos: "O óbice de natureza constitucional que tem sido oposto ao mecanismo do fundo garantidor tem por fundamento o art. 100 da Constituição, que institui o "sistema de precatórios judiciais" como forma de execução das dívidas do Poder Público e impõe a sua liquidação na ordem cronológica da sua apresentação. A execução direta de bens e direitos do fundo garantidor - alegase - estaria fraudando o regime constitucional dos precatórios. Aqui, não se vislumbra qualquer vício. A uma, porque seria legítimo ao Poder Público "desafetar" determinado bem imóvel de seu patrimônio e dá-lo em garantia de um contrato. A desafetação do bem importa a possibilidade de disposição do bem, o que se pode fazer mediante as formas contratuais admitidas pelo Direito. A constituição de uma hipoteca, por exemplo, seria uma forma válida de garantir um contrato de que o Poder Público fosse parte. A duas, porque a fórmula da constituição de uma entidade de direito privado para funcionar como fundo garantidor é absolutamente legítima e respaldada pelo art. 173, $\S 10$, inciso II, da Carta da República. Nada impede, de fato, que o Poder Público constitua uma empresa pública ou uma sociedade de economia mista (ou uma subsidiária dessas entidades) cujo objeto social seja o de garantir determinados projetos, concebidos no formato de PPP. Trata-se de um aspecto da atividade de fomento, que pode ser desempenhada por pessoas estatais de direito privado. (BINENBOJM, Gustavo. As Parcerias Público-Privadas (PPPs) e a Constituição. Salvador: Revista Eletrônica de Direito Administrativo Econômico, n. 2, 2005, p. 14. Disponível em: <http://www.direitodoestado.com/revista/REDAE-2-MAIO-2005-GUSTAVO\%20BINENBOJM.pdf>. Acesso em: 20 nov. 2016.

30 No sentido da inconstitucionalidade, veja-se o trabalho de ACOCELLA, Jéssica. Op. Cit. 
levantar $80 \%$ (oitenta por cento) do valor depositado em juízo pelo expropriante. E, ainda, destaque-se que, na desapropriação amigável, é dispensável a contratação de advogado pelo particular, o que representa uma economia adicional no custeio de defesa técnica em ações de desapropriação.

Apesar de suas evidentes vantagens para todos os envolvidos, a única referência que o DL 3.365/41 faz à desapropriação amigável consta de seu art. 10, segundo o qual a expropriação "deverá efetivar-se mediante acordo ou intentar-se judicialmente", sem estabelecer qualquer incentivo para que a primeira alternativa seja preferível à segunda. Seria extremamente salutar uma reforma no tratamento dispensado pelo ordenamento pátrio às desapropriações, com previsão de uma fase obrigatória de desapropriação amigável no processo, na qual o Poder Público, com base no laudo de avaliação realizado por seus técnicos, ofereceria ao proprietário o valor que entendesse como justo, dando início a um procedimento administrativo de negociação, em uma tentativa de aquisição consensual do bem.

Nesse modelo, a Administração Pública teria o dever de imprimir esforços para que a transferência do bem se consumasse por intermédio de negócio jurídico bilateral, em que o Estado manifestasse a sua intenção de desapropriar, dentro dos limites e possibilidades do interesse público, em concordância com o requerido pelo administrado. Apenas excepcionalmente deveria ser manejada a desapropriação judicial, nos casos em que não houvesse alternativa a não ser a resolução do conflito de interesses entre o ente expropriante e o particular por meio da sua judicialização.

$\mathrm{O}$ acesso ao Poder Judiciário deveria ser utilizado, apenas, como ultima ratio, nas hipóteses em que efetivamente houvesse a frustração das negociações, evitando-se o desperdício de recursos públicos e de tempo. Isso porque a desapropriação amigável, além de contribuir para a aceitação social da expropriação e para a diminuição da litigiosidade, gera significativa eficiência econômica, no que toca à desnecessidade de pagamento das custas processuais e dos honorários advocatícios - sem contar os juros moratórios e compensatórios -, todos estes requeridos em um processo judicial.

Além disso, consideramos que o procedimento de desapropriação amigável deveria ser estendido, nos mesmos moldes, para os processos de remoções de possuidores e outras pessoas atingidas pelo projeto que não possuam justo título de propriedade, adotando-se, nesse caso, as recomendações já trazidas acima em relação à maior proteção desses envolvidos.

O entendimento aqui defendido está em consonância com os já referidos Princípios do Equador, conforme o disposto no Princípio n. 3 sobre os padrões sociais e ambientais 
aplicáveis à aquisição de terras e assentamentos involuntários, cujas diretrizes advêm dos Padrões de Desempenho da International Finance Corporation (IFC), reconhecidas internacionalmente como práticas de mercado que evitam ou minimizam os impactos adversos dos projetos socioambientais. O Padrão de Desempenho n. 5, parágrafo 3, da IFC, traz a excepcionalidade do processo judicial, sendo a regra a realização da fase negocial da desapropriação: "para ajudar evitar a desapropriação e limitar a necessidade de recorrer à autoridade governamental para executar a transferência, os clientes são incentivados a utilizar acordos negociados que atendam aos requisitos deste Padrão de Desempenho, ainda que disponham dos meios legais para adquirir a terra sem o consentimento do vendedor"; enquanto os parágrafos 27 a 29 elencam medidas para que as pessoas desapropriadas sejam indenizadas integralmente pela reposição da perda que sofreram, devendo também ser-Ihes garantido apoio financeiro temporário ${ }^{31}$.

31 "27. As pessoas deslocadas economicamente que sofrerem perda de bens ou de acesso a bens serão indenizadas por essa perda pelo custo integral de reposição.

Nos casos em que a aquisição da terra ou as restrições a seu uso afete estruturas comerciais, os comerciantes afetados serão indenizados pelo custo de restabelecer atividades comerciais em outros locais, pela receita líquida perdida durante o período de transição e pelos custos da transferência e reinstalação da fábrica, das máquinas ou de outros equipamentos.

Nos casos que afetem pessoas que tenham direitos ou pretensões legais à terra que sejam reconhecidos ou reconhecíveis de acordo com a legislação nacional (ver parágrafos 17 (i) e (ii)), será fornecida uma propriedade em substituição (campos agrícolas ou locais comerciais) de valor igual ou maior ou, quando apropriado, indenização pecuniária pelo custo integral de reposição.

As pessoas economicamente deslocadas que não tenham pretensões legalmente reconhecíveis à terra (ver parágrafo 17 (iii)) serão indenizadas por perda de bens que não a terra (como safras, infraestrutura de irrigação e outras benfeitorias feitas à terra) pelo custo integral de reposição. 0 cliente não será obrigado a indenizar nem a prestar assistência a colonos oportunistas que invadam a área do projeto após o prazo final de elegibilidade.

28. Além da indenização pela perda de bens, se houver, conforme exigido no parágrafo 27 , as pessoas economicamente deslocadas cujos meios de subsistência ou níveis de renda sejam afetados adversamente também receberão oportunidades para melhorar ou, pelo menos, recuperar seus meios de auferir renda, níveis de produção e padrões de vida:

Para as pessoas cujos meios de subsistência sejam baseados na terra, deve-se oferecer, como questão de prioridade, uma terra em substituição que combine potencial produtivo, vantagens de localização e outros fatores pelo menos equivalentes àqueles que estejam sendo perdidos.

Para as pessoas cujos meios de subsistência sejam baseados em recursos naturais e para as quais se apliquem as restrições de acesso relacionadas ao projeto previstas no parágrafo 5 , serão adotadas medidas para permitir o acesso contínuo aos recursos afetados ou para fornecer acesso a recursos alternativos com potencial equivalente de obter meios de subsistência e acessibilidade. Quando for apropriado, os benefícios e a indenização associados ao uso dos recursos naturais poderão ter caráter coletivo em vez de serem diretamente canalizados para indivíduos ou domicílios.

Caso as circunstâncias impeçam o cliente de fornecer terra ou recursos semelhantes conforme descrito acima, deverão ser oferecidas oportunidades alternativas para obtenção de renda, como linhas de crédito, treinamento, dinheiro ou oportunidades de emprego. No entanto, a indenização por si só normalmente é insuficiente para recuperar os meios de subsistência.

29. Deve ser proporcionado apoio temporário a todas as pessoas economicamente deslocadas, conforme necessário, com base em uma estimativa razoável de tempo necessário para recuperar sua capacidade de auferir renda, seus níveis de produção e seus padrões de vida".

Revista Publicum

Rio de Janeiro, v. 3, n. 2, 2017, p. 134-165

http://www.e-publicacoes.uerj.br/index.php/publicum

DOI: 10.12957/publicum.2017.29000 
Em que pese a ausência de um regramento geral em relação às desapropriações amigáveis $^{32}$, cada vez mais entes públicos, valendo-se do princípio da consensualidade administrativa, vêm, na prática, adotando tais procedimentos em desapropriações, buscando acordos com os particulares envolvidos na aquisição amigável do bem, tendo em vistas as vantagens que o procedimento oferece para ambas as partes. Em estudo de casos de desapropriação amigável nos Estados do Rio de Janeiro e de São Paulo, pudemos observar que ambos os tribunais têm entendido ser juridicamente viável a utilização do instituto da desapropriação amigável, buscando dar-lhes contornos mais delimitados a partir dos casos concretos apresentados.

O Tribunal de Justiça do Rio de Janeiro (TJRJ) já reconheceu a falta de interesse de agir em ação judicial que visava a rediscutir desapropriação realizada de forma amigável, na medida em que, fixado este montante a partir de um consenso entre aos envolvidos, a conclusão do processo expropriatório prescinde de intervenção judicial. A título exemplificativo ${ }^{33}$, o imóvel de propriedade da Santa Casa de Misericórdia no Município de Vassouras (RJ) foi declarado de utilidade pública e desapropriado pelo ente expropriante, a Municipalidade, que, pretendendo a imissão provisória na posse, ajuizou ação judicial. 0 processo, no entanto, foi extinto, tendo em vista a anterior celebração de termo de compromisso de desapropriação amigável.

Igualmente ${ }^{34}$, não se vislumbra interesse processual se o particular que firmou escritura de desapropriação amigável, recebendo o valor estimado para o imóvel, tem a pretensão de obter complementação, sob o argumento de não ter sido justa a indenização paga pelo Município. Afinal, o proprietário teria a faculdade de dispor de seus bens, sendo certo que o exercício desta disposição, no valor que lhe fosse conveniente, não macularia o negócio jurídico de qualquer vício.

\footnotetext{
32 Há, contudo, alguns regramentos específicos que visam a tornar as ações de desapropriação mais transparentes. Em São Paulo, por exemplo, o Decreto n. 27.869/1987 dispõe sobre os requisitos a serem observados, pelos órgãos da Administração Pública Estadual, nos procedimentos administrativos para a declaração de utilidade pública de bens imóveis. Esse Decreto, modificado pelo Decreto n. 39.250/1994, exige que sejam indicados os recursos financeiros hábeis para o pagamento da indenização devida. E que a Procuradoria do Estado, em não se tratando de declaração de utilidade pública de bens imóveis destinados à concessão de serviço ou obra pública, manifeste-se sobre a regularidade do procedimento pretendido, bem como sobre a existência, ou não, de bens imóveis de propriedade da Fazenda do Estado que possam ser aproveitados como alternativa à desapropriação cogitada no processo.

33 TJ-RJ, Apelação n. 0001725-14.2006.8.19.0065, Rel. Des. Cezar Augusto Rodrigues Costa, DJ 26 mar. 2015.

34 TJ-RJ, Apelação n. 0000455-11.2006.8.19.0014, Rel.a Des.a Nanci Mahfuz, DJ. 29 nov. 2013.
} 
Em casos semelhantes, o Tribunal de Justiça de São Paulo (TJSP) ${ }^{35}$ negou, em decisão de mérito, provimento ao recurso interposto, em vez de se reconhecer a falta de interesse processual. No caso em questão, o imóvel fora objeto de desapropriação amigável firmada entre o Município de Pindamonhangaba e o particular apelante, nada levando a crer que tivesse havido vício de consentimento que gerasse a desconstituição do negócio jurídico. Na inicial, constou pedido de complementação do preço com o pagamento da diferença que o apelante entendia devida, o que restou negado diante da existência de um ato jurídico perfeito e do princípio da segurança jurídica.

Por outro lado, no Tribunal Regional Federal da $1^{\text {ạ }}$ Região ${ }^{36}$, a decisão em processo análogo foi diametralmente oposta. Ao contrário dos precedentes mencionados, oriundos dos Tribunais de Justiça do Rio de Janeiro e de São Paulo, o recurso interposto perante a justiça federal foi provido, sob a consideração de que a transação poderia ser anulada por vício de vontade, com o pagamento da diferença e dos acréscimos legais ao particular, mediante o reconhecimento pela Administração Pública de que foi cometido erro na avaliação do imóvel, que importou pagamento inferior ao valor dos bens, ferindo o princípio constitucional do justo preço.

Já no que se refere às hipóteses de pagamento de valores a maior ao expropriado em sede de desapropriação amigável, o $\operatorname{TJSP}^{37}$ tem admitido a devolução dos valores pagos a maior pelo Poder Público, conforme o disposto no artigo 11 da Lei Federal $\mathrm{n}$. $4.717 / 65^{38}$, com vistas a convalidar o processo de desapropriação amigável, no caso em que a perícia oficial detecta sobrepreço no valor atribuído ao imóvel, e que a anulação da desapropriação causaria danos para o Município, seja para adquirir ou desapropriar terreno com base em valores mais elevados. A fim de que não haja enriquecimento indevido do expropriado - o que também violaria o mandamento constitucional da justa indenização -, tem-se admitido, também, a devolução dos valores pagos em duplicidade, quando houve expedição de precatório para pagamento da indenização e, anteriormente, havia sido feita desapropriação amigável. No caso analisado ${ }^{39}$, o Município de Mogi das Cruzes teve sua apelação provida, em razão da realização de desapropriação amigável antes da sentença de mérito e do depósito do precatório expedido nos autos.

35 TJ-SP, Apelação n. 1000365-75.2014.8.26.0445, Rel. Des. Décio Notarangeli, j. 16 jun. 2016.

36 TRF - 1a Região, Apelação n. 2001.39.00.004879-3, Rel. Des. Fed. Olindo Menezes, DJ. 03 fev. 2006.

${ }^{37}$ TJ-SP, Apelação n. 0001960-16.2013.8.26.0493, Rel. Des. Marcelo Semer, j. 06 jun. 2016.

38 "A sentença que, julgando procedente a ação popular, decretar a invalidade do ato impugnado, condenará ao pagamento de perdas e danos os responsáveis pela sua prática e os beneficiários dele, ressalvada a ação regressiva contra os funcionários causadores de dano, quando incorrerem em culpa".

${ }^{39}$ TJ-SP, Apelação n. 0011803-33.2001.8.26.0361, Rel. Des. Ricardo Anafe, j. 27 set. 2016. 
Ainda com fundamento na justa indenização, o TJRJ vem entendendo que, na hipótese em que a obrigação é assumida, mas não adimplida, é devido o cumprimento integral do termo de compromisso da desapropriação amigável, sob pena de enriquecimento ilícito por parte do ente público. Esse é o exposto no caso originário do Município de Casimiro de $\mathrm{Abreu}^{40}$, em que houve a desapropriação de diversas áreas, avaliadas em quase um milhão de reais, mas o Município não quitou a indenização correspondente (a saber, a realização de diversas obras de infraestrutura no terreno, como a instalação de rede elétrica e de iluminação, sistema de abastecimento de água, esgotamento sanitário e meio-fio, acordadas como forma de indenização pela intervenção do Poder Público na propriedade privada), tendo sido o ente local condenado a cumprir as obrigações assumidas no compromisso de desapropriação amigável, no prazo de um ano, sob pena de multa diária de $\mathrm{R} \$ 1.000,00$ (hum mil reais).

A conclusão a que chegamos a partir dessa análise de casos é que a Constituição da República garante o direito à propriedade, ressalvada a desapropriação por necessidade pública, ou interesse social, por meio do qual o Poder Público retira do patrimônio privado determinado bem, pagando-Ihe, em troca, justa e prévia indenização em dinheiro (art. 5으, XXIV), assim como as demais hipóteses de desapropriação-sanção previstas em seus arts. 182 , 4 4ㅇ, 184 e $243^{41}$. Mas, por outro lado, não define a abrangência do conceito de “indenização justa”, o que causa divergências na doutrina e na jurisprudência quando instadas a delimitar os contornos do conceito jurídico indeterminado do que seria "justa indenização" em sede de desapropriação - seja aquela promovida judicialmente, seja nos procedimentos amigáveis.

Nesse contexto, o ideal é que o intérprete, no exercício da sua autonomia, possa ter um espaço de conformação para dar, em concreto, a resposta mais adequada às situações com as quais se deparar, atentando-se para as especificidades do dano sofrido e para o fato de que o atingimento do direito de moradia, por suprimir mais do que interesses patrimoniais do particular, requer que o valor da indenização corresponda ao

40 TJ-RJ, Apelação n. 0000167-15.2010.8.19.0017, Relạ. Desª. Alcides da Fonseca Neto, j. 31 out. 2016.

${ }^{41}$ Trata-se, aqui, da desapropriação-sanção urbanística, realizada pelo Município, no caso de imóveis urbanos não utilizados ou subutilizados, com pagamento da indenização em títulos da dívida pública, resgatáveis em 10 (dez) anos, na forma do art. 182, § 40 da CF/88; da desapropriaçãosanção para fins e reforma agrária, realizada pela União Federal no caso de imóveis rurais que não estejam atendendo à sua função social, com indenização paga em títulos da dívida agrária, resgatáveis em 20 (vinte) anos, conforme art. 184 da CF/88; e da desapropriação confiscatória (ou expropriação), também realizada pela União Federal sem pagamento de qualquer indenização, de imóveis rurais ou urbanos em que seja encontrado cultivo de plantas psicotrópicas ou trabalho escravo, devendo o bem ser destinado à reforma agrária ou a programas de habitação popular, consoante art. 243 da CF/88. 
real prejuízo que ele irá sofrer. Assim, faz-se necessário destacar a impossibilidade de que incumbam ao expropriado "todos os demais ônus e encargos potencialmente gerados pela decisão expropriatória ${ }^{42 "}$, o que nem sempre corresponde ao mero valor de mercado do bem.

Segundo Jéssica Acocella, "na Colômbia, por exemplo, que possui um sistema avançado e inovador de ordenação da ocupação do solo, a indenização pode ter natureza compensatória, reparatória ou restitutiva, de acordo com as especificidades de cada caso, que determinarão a ponderação proporcional e em concreto dos interesses envolvidos. Já a Constituição do Estado norte-americano de Michigan, com a mesma finalidade, mas de forma mais precisa, estabelece expressamente que, quando a propriedade subtraída consistir na principal moradia do expropriado, o valor indenizatório deverá ser equivalente a, no mínimo, $125 \%$ do valor de mercado do imóvel, acrescido dos demais danos sofridos $^{43 \prime \prime}$.

O estabelecimento de um regramento geral em matéria de desapropriações amigáveis - tal como sugerimos acima - poderia incorporar essas práticas bem sucedidas na experiência do direito comparado, estabelecendo como valor inicial para as negociações na desapropriação amigável aquele montante constante do laudo de avaliação, acrescido dos custos de transação necessários à aquisição do imóvel, como lavra de escritura, obtenção de certidões e pagamento de tributos e outros valores devidos em razão da transferência, mas deixando espaço para que, excepcionalmente, esse valor seja aumentado a depender das circunstâncias do caso concreto, sobretudo nos casos em que o pagamento do valor requerido pelo particular seja mais eficiente do que suportar os custos e a demora inerentes aos procedimentos judiciais de desapropriação.

Por outro lado, entendemos que, diversamente da opção adotada nos EUA, esse regramento deveria trazer apenas parâmetros para os casos em que o montante acordado em sede de desapropriação amigável poderia superar o valor de mercado estabelecido no laudo de avaliação, acrescido dos respectivos custos de transação, sem, contudo, pré-fixar a priori um limite para esse excedente. Isso porque uma norma que previsse de antemão um percentual máximo para a parcela da indenização que excedesse o laudo de avaliação poderia gerar risco moral ${ }^{44}$, incentivando os particulares a exercerem o holdout para

\footnotetext{
42 BAPTISTA, Patrícia. Consensualidade e justo preço nas desapropriações: novos parâmetros à luz do direito administrativo contemporâneo, p. 07. Disponível em: <http://anape.org.br/site/wpcontent/uploads/2014/01/TESE-20-AUTORA-PATR\%C3\%8DCIA-FERREIRA-BAPTISTA.pdf>. Acesso em 10 nov. 2016.

${ }^{43}$ ACOCELLA, Jéssica. Op. Cit. P. 280-281.

44 "O risco moral é caracterizado como a sobreutilização dos serviços de saúde na presença de seguro, ou seja, os indivíduos que possuem algum tipo de plano de saúde tendem a sobreutilizar os 
buscarem - inclusive dentro da lógica do chamando endowment effect (expressão usualmente traduzida como "efeito viúva") ${ }^{45}$ - sempre chegar a esse patamar, mesmo nas situações em que a indenização justa seria apenas a soma do valor de mercado do bem com os custos correspondentes à transferência da propriedade.

Ainda no âmbito das desapropriações amigáveis, é possível também a negociação, junto aos particulares, de instrumentos alternativos de indenização pela perda da propriedade além da mera compensação financeira. O Estatuto da Cidade, em seu art. 35, estabelece a figura da Transferência de Potencial Construtivo ${ }^{46}$, que permite que o expropriado exerça o seu direito de construir em outra localidade, instituto que pode ser especialmente útil nas desapropriações que envolvam a implantação de projetos de infraestrutura que gerem valorização de áreas vizinhas, hipótese em que o expropriado pode se interessar em edificar metragem similar em região que será objeto de valorização após a conclusão da obra.

A Transferência de Potencial Construtivo poderia, a princípio, ser empregada tanto na permuta de bens públicos dominicais, a serem recebidos pelo particular em troca do imóvel expropriado, quanto na transferência de imóveis adquiridos pelo poder público por meio do instituto da desapropriação por zona, os quais poderiam ser transferidos posteriormente aos particulares desalojados para a implantação do projeto. Nessa segunda hipótese, para além da questão moral envolvendo a substituição de um particular por outro no exercício do direito de propriedade fora das hipóteses de interesse social previstas na Lei no 4.132/62 (muito embora, como visto, a jurisprudência pátria considere constitucional o instituto da desapropriação por zon $a^{47}$ ), é recomendável que sejam

serviços, visto que o custo marginal de utilização é zero ou próximo de zero". (MAIA, Ana Carolina; ANDRADE, Mônica Viegas; OLIVEIRA, Ana Maria Hermeto Camilo. O risco moral no sistema de saúde $\begin{array}{lllll}\text { suplementar brasileiro, } & \text { p. } & \text { Disponível }\end{array}$ <http://www.anpec.org.br/encontro2004/artigos/A04A099.pdf>. Acesso em: 20 nov. 2016.

${ }^{45} \mathrm{O}$ endowment effect é uma espécie de viés comportamental, estudado pela Behavioral Law and Economics, que se manifesta quando indivíduos atribuem um valor excessivo e incompatível com a realidade a suas propriedades, provavelmente em razão de algum apego de ordem pessoal ou emocional, ainda que não estejam dispostos a despender o valor que eles próprios atribuem àquele objeto para adquiri-lo. Vide: JOLLS, Christine. Behavioral Law and Economics.(2006). Yale Law School, Public Law Working Paper No. 130; Yale Law \& Economics Research Paper No. 342. Disponível em: <http://ssrn.com/abstract=959177>. Acesso em 06.12.2016.

$46 \mathrm{O}$ instituto vem sendo utilizado de forma pioneira no Brasil pelo Município de Porto Alegre, por meio dos rts. 51 e 52 da Lei Complementar Municipal n. 434/99.

47 No direito comparado, há importante precedente da Suprema Corte dos EUA validando desapropriação levada a efeito com a finalidade de promover a revitalização de uma área degradada da cidade de New London conhecida como Fort Trumbell. No caso Kelo v. City of New London, julgado em 2005, a Suprema Corte Americana decidiu, por 5 votos a 4, que a revitalização econômica de uma determinada área já degradada há décadas se enquadraria no conceito constitucional de public use, que designa um dos pressupostos constitucionais mínimos a autorizar o exercício legítimo do poder eminente pelo Estado, conforme estabelece a $5^{\text {a }}$ Emenda da 
elaborados estudos técnicos que demonstrem a eficiência econômica de se ampliar a área expropriada (atingindo mais proprietários) para que os particulares diretamente afetados pelo projeto possam ser realocados, por meio da Transferência de Potencial Construtivo, na região que se tornará vizinha ao empreendimento - cujos proprietários originais terão seus imóveis desapropriados pelo valor de mercado anterior à realização da obra.

\section{Considerações finais}

No presente artigo, analisamos algumas medidas que têm como objetivo trazer um incremento de eficiência aos processos de remoção e desapropriação, considerando, sobretudo, os custos bastante consideráveis do orçamento total dos projetos de infraestrutura e as dificuldades ligadas à sua concretização, que são causas frequentes do atraso na entrega dos empreendimentos de grande porte.

Não por outro motivo, e considerando também a desproteção dos direitos patrimoniais dos expropriados no regime do Decreto-Lei no 3.365/1941, procuramos contribuir para o debate cerca da construção de novos modelos jurídicos para os projetos de infraestrutura de que o Brasil tanto necessita, partindo do entendimento de que o progresso é salutar, mas não a qualquer custo. Por isso, o custeio das indenizações devidas em processos de remoção e desapropriação deve pressupor a realização de estudos apropriados sobre o dispêndio dos recursos públicos, a fim de que ele seja pensado não só sob o viés do risco de seleção adversa de um dimensionamento equivocado - tanto para cima quanto para baixo, mas também quanto às chances de se mostrar conveniente e até inevitável a celebração de aditivos contratuais para a readequação do montante inicialmente estimado.

Nesse sentido, as propostas ora apresentadas têm como fundamento o oferecimento de auxílio e reassentamento adequados às pessoas afetadas, bem como a preferência obrigatória pela desapropriação amigável em detrimento da judicial, buscando a minimização do tempo e dos custos de transação - inclusive políticos, envolvidos nos processos de implantação de projetos de infraestrutura, consoante com as diretrizes traçadas no direito comparado e nos Princípios do Equador.

Constituição norte-americana ("nor shall private property be taken for public use without just compensation"). 


\section{Referências}

ACOCELLA, Jéssica. Uma releitura da Desapropriação à Luz da Constituição de 1988 e suas Principais Repercussões sobre o Regime Jurídico Vigente. 2013. Dissertação (Mestrado) Curso de Direito Público, Universidade do Estado do Rio de Janeiro, Rio de Janeiro, 2013.

ARAGÃO, Alexandre Santos de. Teorias pluralistas das fontes de direito: lex mercatoria, ordenamentos setoriais, subsistemas, microssistemas jurídicos e redes normativas. Revista Trimestral de Direito Civil, Rio de Janeiro, v. 36, p.3-36, out/dez. 2008.

BAPTISTA, Patrícia. Consensualidade e justo preço nas desapropriações: novos parâmetros à luz do direito administrativo contemporâneo. Disponível em: <http://anape.org.br/site/wp-content/uploads/2014/01/TESE-20-AUTORA-

PATR\%C3\%8DCIA-FERREIRA-BAPTISTA.pdf>. Acesso em 10 nov. 2016.

BARROSO, Luís Roberto. A razão sem voto: o Supremo Tribunal Federal e o governo da maioria. Revista Brasileira de Políticas Públicas, Brasília, v. 5, n. 2, p.40-41. 2015. Número Especial.

BINENBOJM, Gustavo. As Parcerias Público-Privadas (PPPs) e a Constituição. Revista Eletrônica de Direito Administrativo Econômico, Salvador, n. 2, p.14, mai/jun/jul. 2005. Disponível em: <http://www.direitodoestado.com/revista/REDAE-2-MAIO-2005-GUSTAVO BINENBOJM.pdf>. Acesso em: 20 nov. 2016

BUCHANAN, James M.; TULLOCK, Gordon. The Calculus of Consent: Logical Foundations of Constitutional Democracy. Ann Arbor: University of Michigan Press, 1962 E: Rowley, Charles K., and Friedrich Schneider, eds. The Encyclopedia of Public Choice. 2 vols. Boston: Kluwer, 2004.

CARVALHO FILHO, José dos Santos. Manual de Direito Administrativo. 23. ed. Rio de Janeiro: Lumen Juris, 2009.

COASE, Ronald Henry. The nature of the firm. Economica, v. 4, p. 386-405, 1937. The nature of the firm: meaning. In: WILLIAMSON, O. E.; WINTER, S. G. (Ed.). The nature of the firm: origins, evolution and development. Oxford: Oxford University Press, 1991. p. 48-60.

JOLLS, Christine. Behavioral Law and Economics.(2006). Yale Law School, Public Law Working Paper No. 130; Yale Law \& Economics Research Paper No. 342. Disponível em: <http://ssrn.com/abstract=959177>. Acesso em 06.12.2016.

MAIA, Ana Carolina; ANDRADE, Mônica Viegas; OLIVEIRA, Ana Maria Hermeto Camilo. $O$ risco moral no sistema de saúde suplementar brasileiro. Disponível em: <http://www.anpec.org.br/encontro2004/artigos/A04A099.pdf>. Acesso em: 20 nov. 2016.

MELLO, Celso Antônio Bandeira de. Curso de Direito Administrativo. 26. ed. São Paulo: Malheiros Editores, 2009. p. 881

MORALES, María Luisa Martín. Necesidad de la ocupación de bienes o adquisición de derechos. In: OLIVEIRA, Tomás Cobo (Org.). Los procedimientos administrativos expropiatórios: tutela frente a las actuaciones de la Administración. Barcelona: Editorial Bosch, 2011. p. 192. 
MOREIRA NETO, Diogo de Figueiredo. Teoria do poder: sistema de direito político: estudo juspolítico do poder. Editora Revista dos Tribunais, São Paulo, 1992.

O GLOBO. Em Nova York, se você ganha pouco, entre pela porta dos fundos. Disponível em: <http://oglobo.globo.com/economia/em-nova-york-se-voce-ganha-poucoentre-pela-porta-dos-fundos-15384556>. Acesso em: 07 dez. 2016.

ORGANISATION FOR ECONOMIC CO-OPERATION AND DEVELOPMENT. The 2012 Common Approaches. Disponível em: <http://www.oecd.org/tad/xcred/the2012commonapproaches.htm>. Acesso em: 05 nov. 2016.

RIBEIRO, Mauricio Portugal. Desapropriações $e$ desocupações em concessões $e$ PPPs: custos, riscos, sensibilidade política e os Princípios do Equador. Disponível em: $<$ http://www.slideshare.net/portugalribeiro/desapropriao-e-reassentamento-final-parapublicacao>. Acesso em: 08 ago. 2017.

ROLNIK, Raquel. Você já foi desapropriado? Foi feliz? 2013. Disponível em: <https://raquelrolnik.wordpress.com/2013/07/25/voce-ja-foi-desapropriado-foi-feliz/>. Acesso em: 14 dez. 2016.

SENN, Myriam. Non-state regulatory regimes: understanding institutional transformations. Disponível em: <https://papers.ssrn.com/sol3/papers.cfm?abstract_id=2377900> Acesso em: 08 ago. 2017.

THE EQUATOR PRINCIPLES. A financial industry benchmark for determining, assessing and managing environmental and social risk in projects. 2013. Disponível em: <http://www.equator-principles.com/resources/equator_principles_III.pdf>. Acesso em: 05 nov. 2016.

\section{Enviado em: 02/06/2017}

Aprovado em: 12/08/2017 